\title{
Variability in Environmental Conditions Strongly Impacts Ostracod Assemblages of Lowland Springs in a Heavily Anthropized Area
}

\author{
Giampaolo Rossetti ${ }^{*}+{ }^{\dagger}$, Valentina Pieri ${ }^{\dagger} \ddagger$, Rossano Bolpagni ${ }^{\mathbb{D}}$, Daniele Nizzoli ${ }^{\mathbb{D}}$ \\ and Pierluigi Viaroli \\ Department of Chemistry, Life Science and Environmental Sustainability, University of Parma, \\ 43124 Parma, Italy; valentina.pieri@gmail.com (V.P.); rossano.bolpagni@unipr.it (R.B.); \\ daniele.nizzoli@unipr.it (D.N.); pierluigi.viaroli@unipr.it (P.V.) \\ * Correspondence: giampaolo.rossetti@unipr.it \\ † These authors contributed equally to this work. \\ $\ddagger$ Present address: Iren Laboratori S.p.A., Piacenza, Italy.
}

Received: 6 October 2020; Accepted: 17 November 2020; Published: 21 November 2020

\begin{abstract}
The Po river plain (Northern Italy) hosts artificial, lowland springs locally known as fontanili, which provide important ecosystem services in an area dominated by intensive agricultural activities. Here we present a study carried out in 50 springs. Each spring was visited once from October 2015 to January 2016. The sampled sites were selected to include springs studied in 2001 and 2004, to evaluate changes in water quality and ostracod assemblages that possibly occurred over a period of 10-15 years, and explore the relationships between ostracod community composition and water physical and chemical variables. Our results showed a decrease in the chemical water quality especially, in springs south of the Po river, evidenced by high nitrate levels. Most of the studied springs showed a relevant decrease in dissolved reactive silica, probably related to recent transformations of either agricultural practices or crop typology. Ostracods were mostly represented by common and tolerant species, and communities were characterized by low alpha diversity and high species turnover. Water temperature and mineralization level were the most influential variables in structuring the ostracod communities. We stress the need to implement conservation and restoration measures for these threatened ecosystems, to regain their role as ecosystem services providers.
\end{abstract}

Keywords: groundwater dependent ecosystems; Northern Italy; hydrochemistry; nutrient stoichiometry; non-marine ostracods; ecosystem services

\section{Introduction}

A large number of semi-artificial, groundwater-dependent ecosystems (GDEs), locally known as "fontanili", occur in the Po and Venetian plains (Northern Italy) along the alluvial fans and terrace deposits of watercourses in the transition zone from higher to lower plain. Across this so-called spring belt, due to changes in both terrain slope and sediment grain size [1-4], groundwater outflows through aquifers under a natural hydraulic gradient occur, which are usually further facilitated by driving perforated pipes and soil excavation. Most of the fontanili can be classified as rheo-limnocrenic springs [5]. The prevalent morphology consists of a spring area, known as "head", which is relatively deep and where the water is almost still, and a drainage channel through which water flows downstream. In order to maintain suitable hydrological conditions, these systems require periodic management to remove the aquatic vegetation and the accumulation of organic sediment. 
Lowland springs are often described as stable habitats, with modest changes in hydrological, thermal, chemical, and biological characteristics, as they are fed by aquifers that guarantee relatively constant conditions at seasonal and interannual timescales $[2,6]$.

The fontanili were exploited over centuries as micro-climate regulators in the lowland grassland of Lombardy. Here, until the late 1960s, in the cold season, stable meadows (locally called "marcite") were submerged in water from lowland springs at nearly $10-12{ }^{\circ} \mathrm{C}$, a temperature much greater than the atmospheric one and sufficient to allow a slight warming and to avoid water freezing. Therefore, the productivity of such meadows was higher compared to traditional lawns.

Lowland springs are components of interconnected systems of lentic waters, streams and channels, where nutrients can be removed by both aquatic vegetation and microbial processes $[7,8]$. They host relict (palaeo-) endemics, i.e., cold-stenotherm plants and animal taxa which underwent altitudinal displacements from mountain areas during the Würm glacial expansion, whose persistence is strictly linked to the conservation of these peculiar "ecological islands" surrounded by human-dominated landscapes [9-11]. Overall, lowland springs are refuge areas for species suffering strong declines in the study area, e.g., pike (Esox lucius) [12].

Despite their great potential value as ecosystem services providers, poor or inappropriate management practices, excessive water abstraction, land reclamation due to agricultural activities and the expansion of grey infrastructures, the spreading of alien species and the impacts of climate change on hydrology are threatening the conservation status of lowland springs [13-16]. Moreover, agriculture affects surface and groundwater quality due to the application of fertilizers that are largely in excess compared with crop uptake, resulting in a sensible increase in nutrient concentrations in most of these GDEs [17,18].

The hydrochemical and ecological features of the fontanili are relatively well studied [2,19-21], especially in the central area of the Po river plain [17,22-24]. In particular, two studies have investigated the relationships between water chemistry and ostracod assemblages [10,15]. Ostracods (class Ostracoda) are small bivalved crustaceans occurring in almost all aquatic ecosystems, mostly in benthic and periphytic habitats. According to Meisch et al. [25], there are presently 2330 subjective species of non-marine ostracods in 270 genera, all belonging to the order Pocodocopida. The Italian non-marine ostracod fauna consists of about 160 species, and it is currently the most diverse in Europe [26].

Accumulating evidence indicates that non-marine ostracods differently respond to environmental conditions, and may be used as bioindicators [27-35]. Their potential as environmental indicators has long been recognized by palaeolimnologists, who infer temporal changes in the local environment from changes in the assemblages of calcified ostracod valves [36-38].

The present research aimed at comparing the current hydrochemical status and the composition of the ostracod communities of 50 lowland springs of the Po river plain with those reported in previous studies carried out in the period 2001-2004 [10,15]. The magnitude of changes was statistically estimated using univariate methods, both between and within different sub-catchments to identify possible spatial patterns. Particular attention was paid to the trends of the stoichiometric ratios of the major dissolved nutrients. In addition, the distribution patterns and the compositional turnover of the ostracod communities over the considered time period were investigated, and the relationships between ostracod occurrence and environmental variables were evaluated by multivariate analysis. The results of this study can be used to assess the often-presumed stability of lowland springs, in terms of weak or delayed responses to anthropic disturbance in their hydrochemical and biological characteristics, and to provide insights into the potential future trajectories of these threatened ecosystems.

\section{Materials and Methods}

\subsection{Study Area}

The study area encompassed 59 lowland springs belonging to nine sub-catchments of the Po river, located in five provinces: Piacenza and Parma in the Emilia-Romagna region (Apennine side of 
the Po plain, south of the Po river), and Lodi, Cremona and Milano in the Lombardy region (Alpine side of the Po plain, north of the Po river) (Table S1, Figure 1). Each spring was visited once between October 2015 and January 2016. Samples were collected from each active spring, 29 in Emilia-Romagna (identified with the codes "PC" and "PR" followed by a number) and 21 in Lombardy (code "S" followed by a number). All the sampled sites were also included in the studies by Rossetti et al. [10] and Pieri et al. [15] on springs in Emilia-Romagna and Lombardy, respectively (same site codes as above). In Rossetti et al. [10], sampling took place between May and August 2001, and each spring was sampled once; in Pieri et al. [15], each spring was sampled twice, in summer (late June-early September) and autumn (November) 2004.

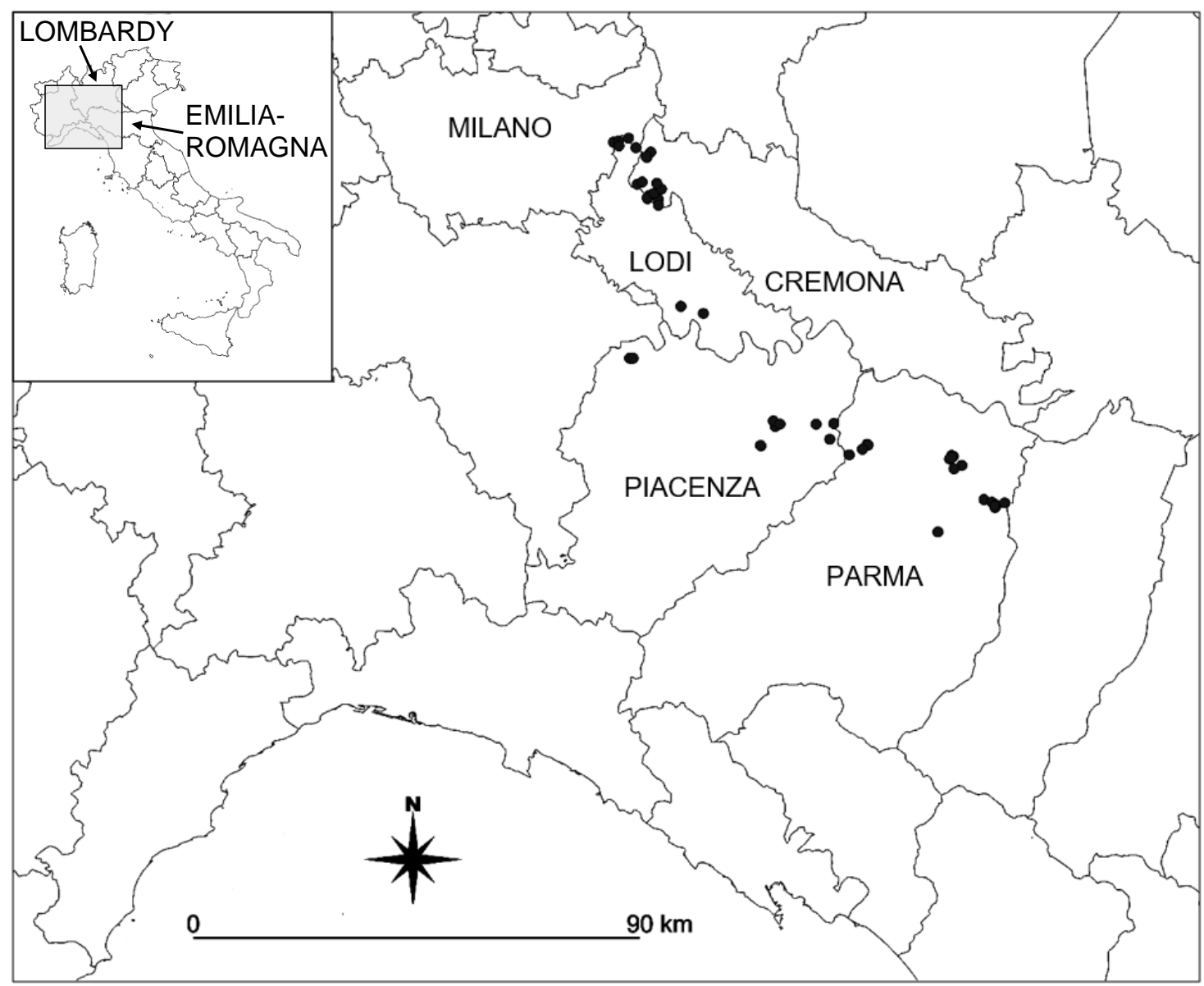

Figure 1. Upper left panel: map of Italy in which the Lombardy and Emilia-Romagna regions are indicated, as well as the grey area corresponding to the main panel. Main panel: location of sampling sites (black dots) in the provinces of Parma and Piacenza (Emilia-Romagna) and Lodi, Cremona and Milano (Lombardy).

\subsection{Field and Laboratory Techniques}

Water samples were collected from each site in the head of the spring. Water temperature $(\mathrm{T})$, conductivity at $25^{\circ} \mathrm{C}(\mathrm{EC}), \mathrm{pH}$ and dissolved oxygen (DO) were measured using a multiparameter probe (Hanna, Mod. HI 9828). Water samples for chemical analysis were immediately filtered $(0.45 \mu \mathrm{m})$ and stored at $4{ }^{\circ} \mathrm{C}$ until they were analyzed. Within $24 \mathrm{~h}$, samples were analyzed for total alkalinity (TA) (Gran titration; [39]), ammonia [40], nitrite [39], nitrate after reduction to nitrite over cadmium columns [39], dissolved reactive silica (DRSi) [39] and soluble reactive phosphorus (SRP) [41].

Qualitative ostracod samples were gathered by a $250 \mu \mathrm{m}$ handnet, pulling it close to the sediment and sweeping it through the vegetation. Living samples were transferred to the 
laboratory, where ostracods were sorted under a binocular microscope and then fixed in $90 \%$ ethanol. Only specimens allowing unambiguous identification (i.e., adults and last juvenile stages) were considered; for Neglecandona gr. neglecta and Herpetocypris sp., the specific allocation remained uncertain because, respectively, only females and early stages were available. Both soft parts (dissected in glycerine and stored in sealed slides) and valves (stored dry in micropaleontological slides) were checked for the taxonomic identification, using González Mozo et al. [42] for Herpetocypris, Mazzini et al. [43] for Ilyocypris, and Meisch [44] for the remaining taxa.

\subsection{Data Analysis}

Box-plots were used to illustrate the range of values of physico-chemical variables in different spring groups and periods. The ordination of abiotic and biotic data was carried out through principal component analysis (PCA) and canonical correspondence analysis (CCA). PCA was performed on the matrix of log-transformed (except for $\mathrm{pH}$ ) physical and chemical water variables to assess their influence on the springs' water quality. The concentration of dissolved inorganic nitrogen (DIN) was the sum of nitrate, nitrite, and ammonia. The same matrix and the ostracod absence/presence data were used to assess possible relationships between ostracod distribution and environmental data by CCA. The significance of canonical axes was assessed by Monte Carlo permutation tests (9999 permutations). Pearson correlation was used to evaluate the correlation degree between environmental variables, and Student's $t$ tests and Mann-Whitney $U$ tests were used to assess possible differences between means and medians of the measured variables, respectively. Statistical analyses were performed using PAST ver. 4.03 [45].

\section{Results}

\subsection{Physical and Chemical Variables}

\subsubsection{Water Characteristics of Springs}

Nine (PR34, PR40, S04, S10, S14, S16, S18, S19 and S20) out of the 59 sites sampled in 2001 and 2004 were found dry during the survey carried out in 2015-2016. T ranged between 9.1 and 14.1 in the Apennine side springs (the only exception was PR39 with $5.1^{\circ} \mathrm{C}$ ), and from 13.8 to $17.6^{\circ} \mathrm{C}$ in the Alpine side springs. The EC values showed a strong variability, with a median significantly higher (Mann-Whitney $U$ test, $p<0.01$ ) in the Apennine springs (range from 450 to $2037 \mu \mathrm{S} \mathrm{cm}{ }^{-1}$, median $731 \mu \mathrm{S} \mathrm{cm}^{-1}$ ) than in Alpine ones (range from 211 to $896 \mu \mathrm{S} \mathrm{cm}^{-1}, 481 \mu \mathrm{S} \mathrm{cm}^{-1}$ ) (Figure 2). Oxygen undersaturation was frequently found, close to hypoxia $(<30 \%)$ in PC03 and PC 32 . Concurrently, distinct oxygen oversaturation $(>160 \%)$ was observed in PR01 and PR39. The $\mathrm{pH}$ values were slightly to moderately alkaline, between 7.3 and 8.2 (Figure 2). 


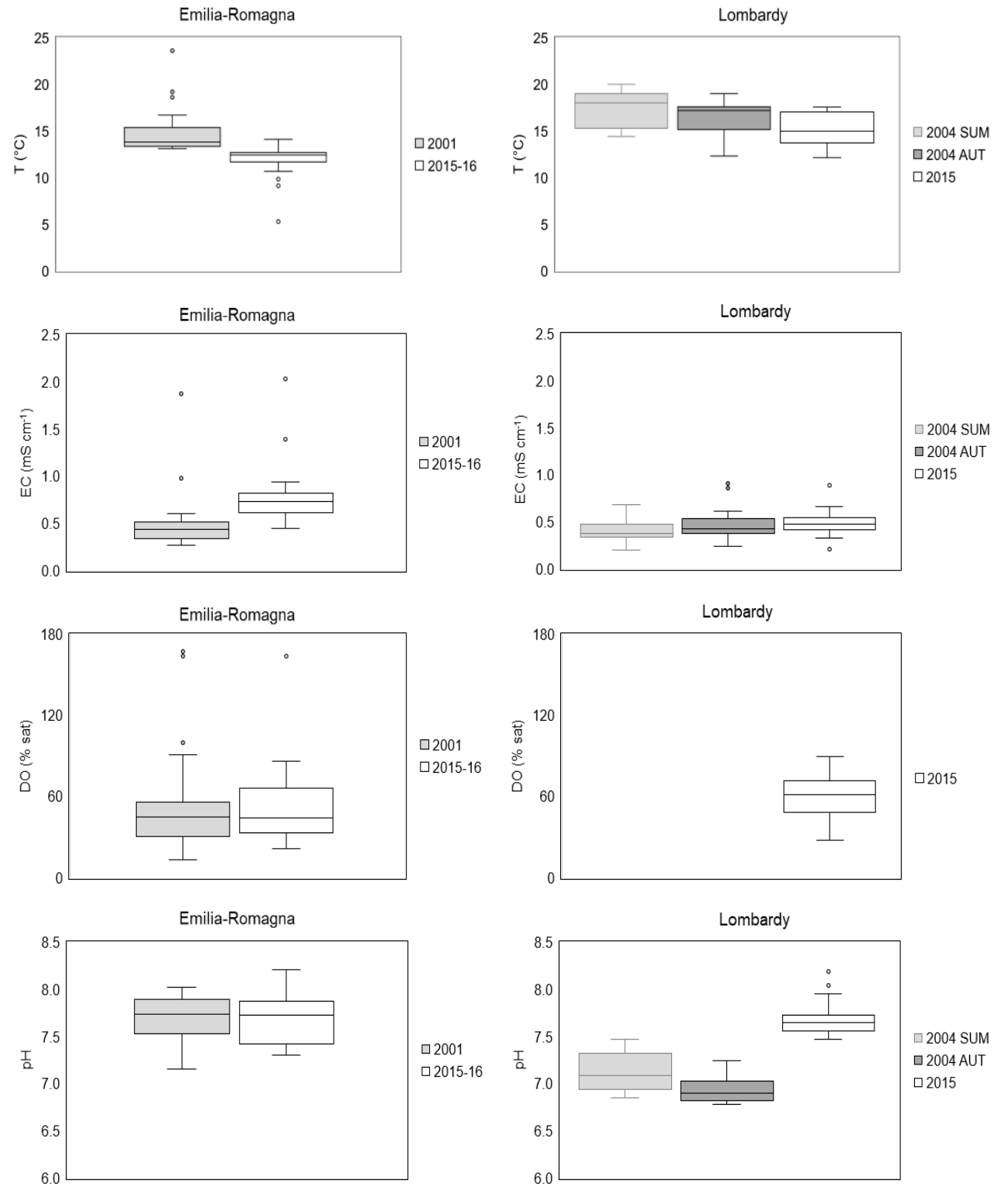

Figure 2. Box-plots showing comparison between water temperature (T), conductivity (EC), dissolved oxygen (DO) and $\mathrm{pH}$ values measured in the present study and in previous research $[10,15]$. The boxes show the 25 th and 75 th percentile (interquartile) ranges. Median values are shown as a horizontal black bar in each box. The whiskers extend up from the top of the box to the largest value that is $\leq 1.5$ times the interquartile range, and down from the bottom of the box to the smallest value that is $>1.5$ times the interquartile range. Values outside this range are considered as outliers and are represented by dots. SUM: summer; AUT: autumn. No DO data available for springs of Lombardy in 2004.

The TA values were typical of well-buffered waters, with a minimum of 2.14 meq $\mathrm{L}^{-1}$ and a maximum of $8.44 \mathrm{meq} \mathrm{L}^{-1}$. On average, SRP concentrations were slightly lower in the Apennine side springs (usually from below the detection limit to $20 \mu \mathrm{g} \mathrm{P} \mathrm{L}{ }^{-1}$, except for isolated peaks up to $45 \mu \mathrm{g} \mathrm{P} \mathrm{L}^{-1}$ ) compared to the Alpine side springs, where values ranged between 3 and $42 \mu \mathrm{g} \mathrm{L}{ }^{-1}$. Nitrate represented on average $>99 \%$ of DIN. Springs in the Apennine side had significantly higher (Mann-Whitney $U$ test, $p<0.05$ ) median DIN concentrations (range from 3.43 to $20.82 \mathrm{mg} \mathrm{N} \mathrm{L}^{-1}$, median $9.62 \mathrm{mg} \mathrm{N} \mathrm{L}^{-1}$ ) than springs in the Alpine side (range from 1.04 to $17.02 \mathrm{mg} \mathrm{N} \mathrm{L}^{-1}$, median $3.38 \mathrm{mg} \mathrm{N} \mathrm{L}^{-1}$ ). Furthermore, the DRSi concentrations had medians significantly larger (Mann-Whitney $U$ test, $p<0.01$ ) in the Apennine side (range between $1.18 \mathrm{mg} \mathrm{Si} \mathrm{L}^{-1}$ and $5.93 \mathrm{mg} \mathrm{Si} \mathrm{L}^{-1}$ ) than in the Alpine side (range between $0.51 \mathrm{mg} \mathrm{Si} \mathrm{L}^{-1}$ and $2.71 \mathrm{mg} \mathrm{Si} \mathrm{L}^{-1}$ ) (Figure 3). 

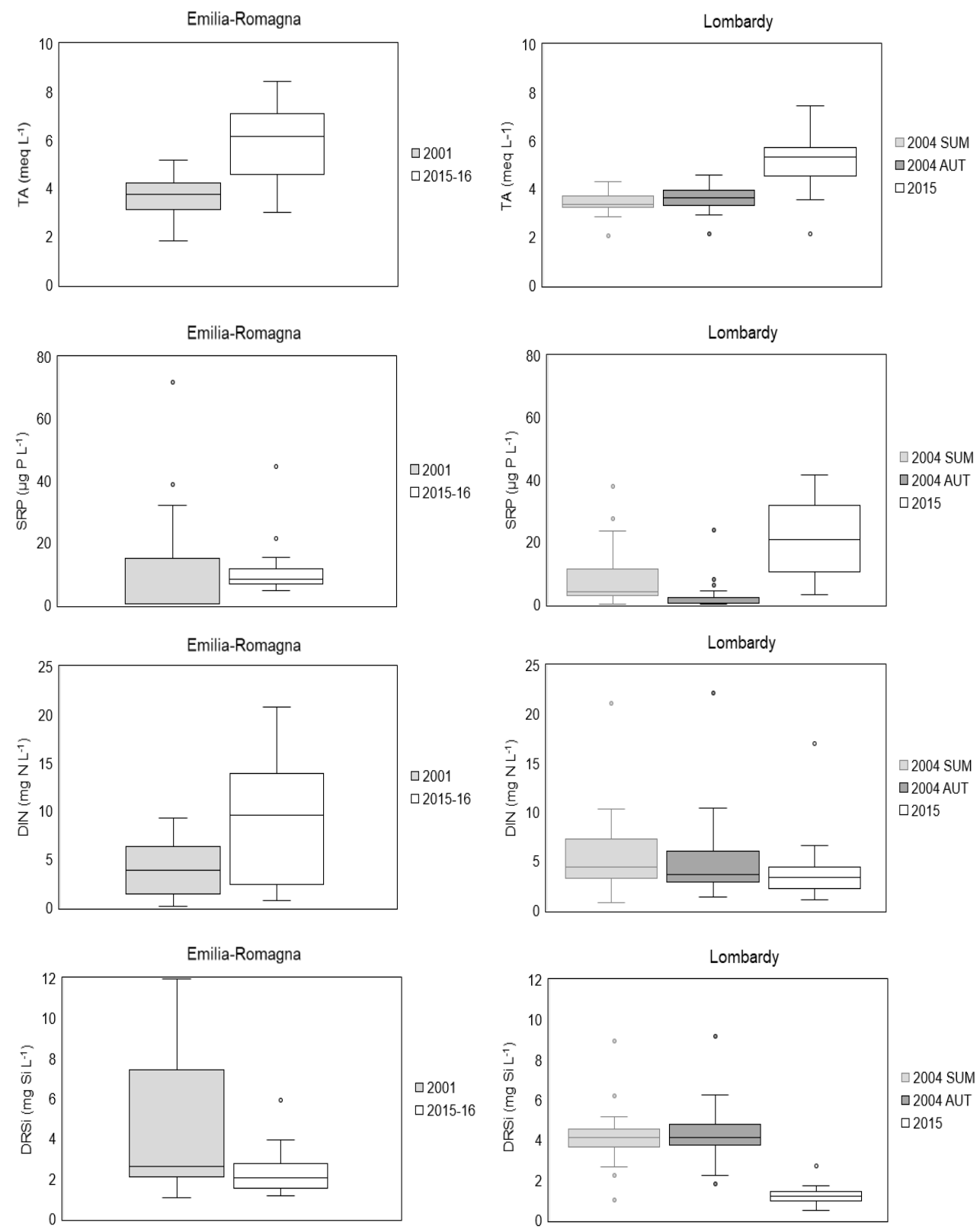

Figure 3. Box-plots showing comparison between TA, SRP, DIN, and DRSi values measured in the present study and in previous research $[10,15]$. Symbols of box-plots are as in Figure 2.

\subsubsection{PCA Results}

The first two axes of the PCA account for $74.70 \%$ of the total cumulative variance. PCA axis 1 was primarily defined by loading of DIN (0.96) and EC (0.82), and PCA axis 2 by loading of SRP (0.73) and $\mathrm{T}(0.35)$ (Figure 4). 


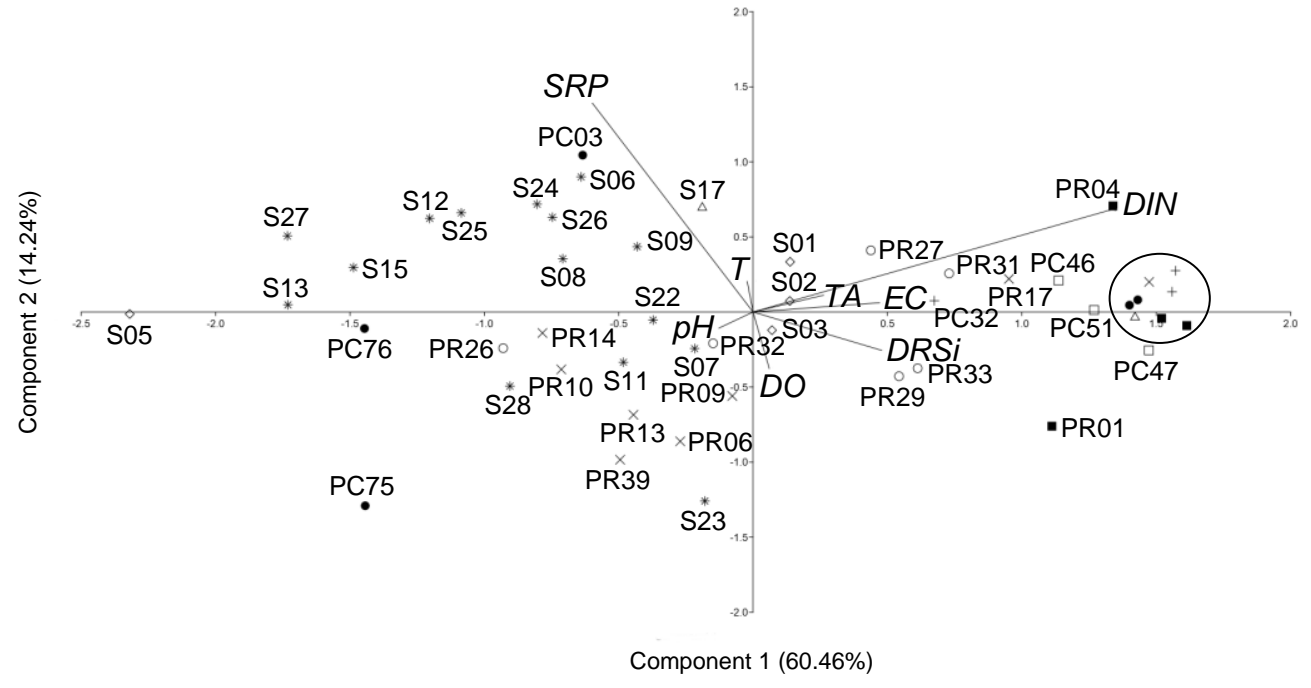

Figure 4. Principal component analysis (PCA) diagram representing the ordination of springs in relation to environmental variables. T: temperature; EC: electric conductivity; TA: total alkalinity; DO: dissolved oxygen saturation; SRP: soluble reactive phosphorus; DRSi: dissolved reactive silica; DIN: dissolved inorganic nitrogen. Point symbols refer to sub-catchments (Chiavenna: •; Arda-Ongina: +; Staffora-Luria-Versa-Coppa: $\square$; Taro: $\mathbf{~}$; Parma: X; Enza: $\bigcirc$; Lambro-Olona meridionale: $\diamond$; Adda: *; Po: $\triangle$ ).

In the plane formed by the first two axes, springs located in the same sub-catchment generally do not form well-defined individual clusters. The springs of the Arda-Ongina, Staffora-Luria-Versa-Coppa and Taro sub-catchments, and most of those of the Enza, are located in the positive part of the first axis, due to the presence of more mineralized waters and, in particular, of higher DIN concentrations. The sites of the Adda sub-catchment are distributed in the third and fourth quadrants, denoting relatively low concentrations of DIN and a marked variability for SRP. Except for PR17 and PR20, the springs of the Parma sub-catchment are located in the third quadrant, indicating lower contents of both dissolved nitrogen and phosphorus compared to other springs in the study area (Figure 4).

\subsubsection{Comparison with Previous Studies}

The springs of the study area had a relative thermal stability, although the $\mathrm{T}$ values notably deviated from the average in some springs of the Apennine side (Figure 2). Conversely, the comparison of aggregated chemical data with previous studies showed different levels of variability in both sides of the watershed.

The most evident changes in the Apennine side springs between 2001 and 2015-2016 can be observed for EC and TA, DIN, and DRSi (Figures 2, 3 and 5). A positive linear correlation between TA and EC was found in both the Apennine and Alpine sides of the Po river $(\mathrm{r}=0.49, p<0.01$ and $\mathrm{r}=0.94$, $p<0.01$, respectively). An increase in the mean values of EC, TA and DIN, and a decrease in DRSi, affected all the sub-catchments, although these variations were not always significant; in addition, there was a strong variability among sub-catchments as regards the mean values of these variables. The DRSi to DIN molar ratio was similar or slightly lower in 2015-2016 compared to 2001 in the springs of the Chiavenna sub-catchment and in three springs of the Enza sub-catchment. All the remaining springs underwent a marked decrease in the ratio over the considered period; the most pronounced change occurred in PR39, from 31.26 to 0.79 , a variation that was however clearly anomalous compared to those of the other springs in the investigated area. 

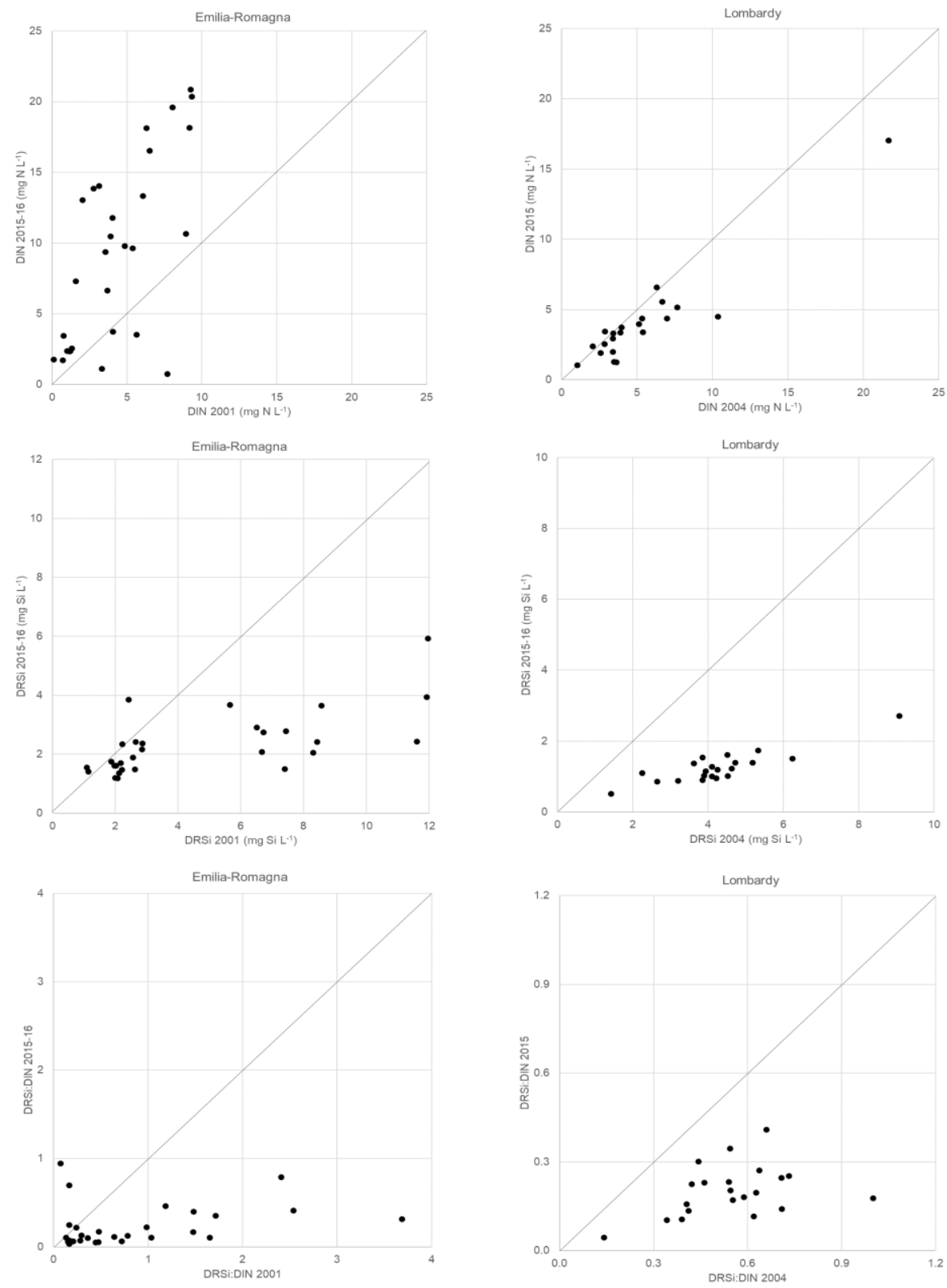

Figure 5. Comparison between DIN and DRSi concentrations, and DRSi to DIN molar ratio (except for PR39, which scores lie outside the graph) for springs of Emilia-Romagna and Lombardy in 2015- 2016 and in previous studies. Note that axis scales are different for each graph.

In the springs of the Alpine side, EC, and to a lesser extent also DIN, showed substantial stability between the two study periods; on the contrary, the other variables exhibited evident changes, in particular DRSi and SRP, the latter often being below the detection limit of the analytical method (Figures 2, 3 and 5). A decrease in DRSi to DIN molar ratio from 2004 and 2015 was observed in all the springs (Figure 5), and the SRP was strongly imbalanced with respect to DRSi and DIN in both periods. A particularly high variability was found in DIN and DRSi concentrations. The large standard deviations compared to means indicated that most hydrochemical variables exhibited high variability, even among springs within close geographic proximity in the same sub-catchment (Table 1). 
Table 1. Comparison using Student's $t$-test of means \pm SD for selected physico-chemical variables in different sub-catchments of Emilia-Romagna (Apennine side) and Lombardy (Alpine side). Data from this study, [10] and [15]. For Lombardy, in 2004, only data collected in autumn are considered. N: number of springs; SL: significance level (NS: not significant; ${ }^{*}: p<0.05 ;{ }^{* *}: p<0.01$ ); NA: not applicable.

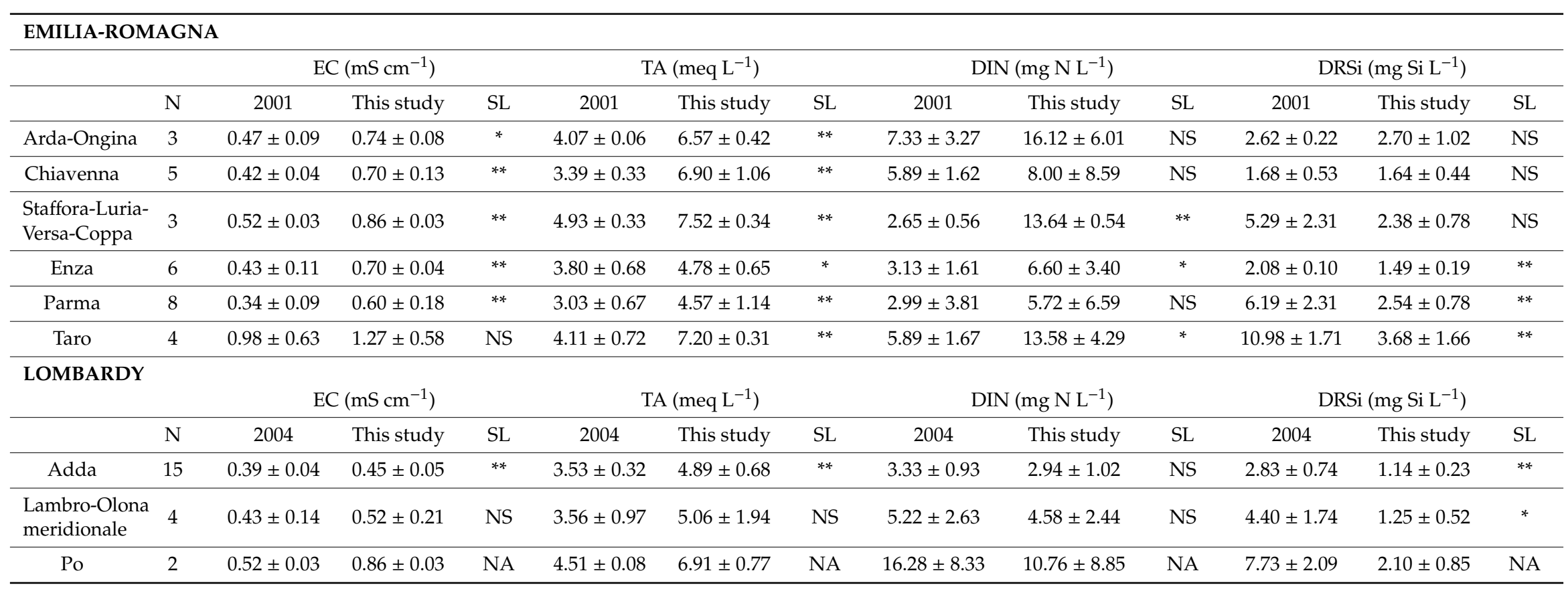




\subsection{Ostracod Assemblages}

In total, 19 taxa, included in 12 genera in four families (Candonidae, Ilyocyprididae, Notodromadidae and Cyprididae), were identified (Table 2). The mean number of taxa per site was 2.5 in Lombardy and 2.2 in Emilia-Romagna. The highest ostracod diversity (five taxa) was found in PR14, PR17 and S09; 14 springs hosted only one species, and sampling in PC32 did not yield any ostracod. The most frequent species were Cypria ophthalmica (in 37 sites), Cypridopsis vidua (14), and Prionocypris zenkeri (13). These three species, plus Ilyocypris inermis, I. bradyi and Herpetocypris reptans, were recorded in the whole study area. Candona candida, Herpetocypris brevicaudata, Heterocypris reptans, Ilyocypris gibba, Potamocypris smaragdina and Scottia pseudobrowniana were collected only in Lombardy. On the other hand, Cyclocypris laevis, Cyc. ovum, Candona gr. neglecta, Herpetocypris sp., Het. salina, Notodromas persica and Pseudocandona lobipes were exclusively found in Emilia-Romagna. Only seven sites, all located in Emilia-Romagna, did not show changes compared to previous surveys in their ostracod composition, possibly indicating a high compositional turnover in the communities of the studied springs. As for the diversity of the entire investigated area, out of a total of 25 identified ostracod taxa, 14 were reported both in this study and in the previous years, 5 only in this study, and 6 exclusively in earlier surveys; at a generic level, the sole difference was the occurrence of Potamocypris in this study (Table 2). 
Table 2. Comparison between ostracod assemblages found in 2015-2016 and in previous studies [10,15] in each sampling site. A: taxa recorded in all surveys; B: taxa absent in 2015-2016 but encountered in previous surveys; C: taxa found in 2015-2016 but absent in previous surveys. $\Sigma$ : number of total records for each taxon in 2015-2016.

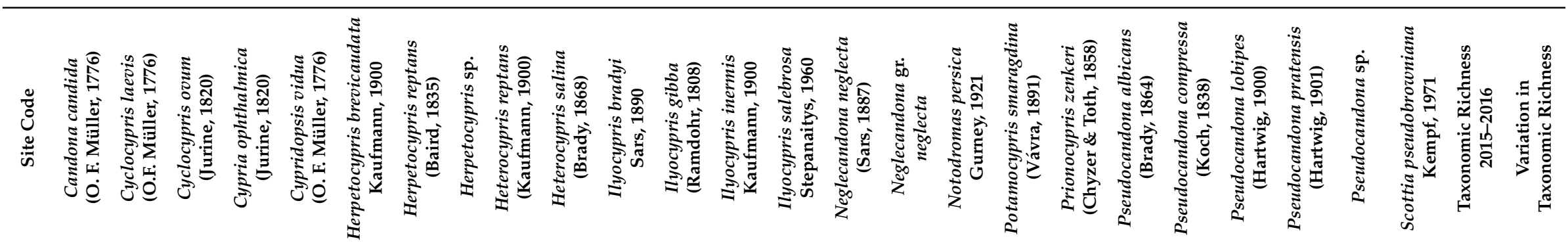

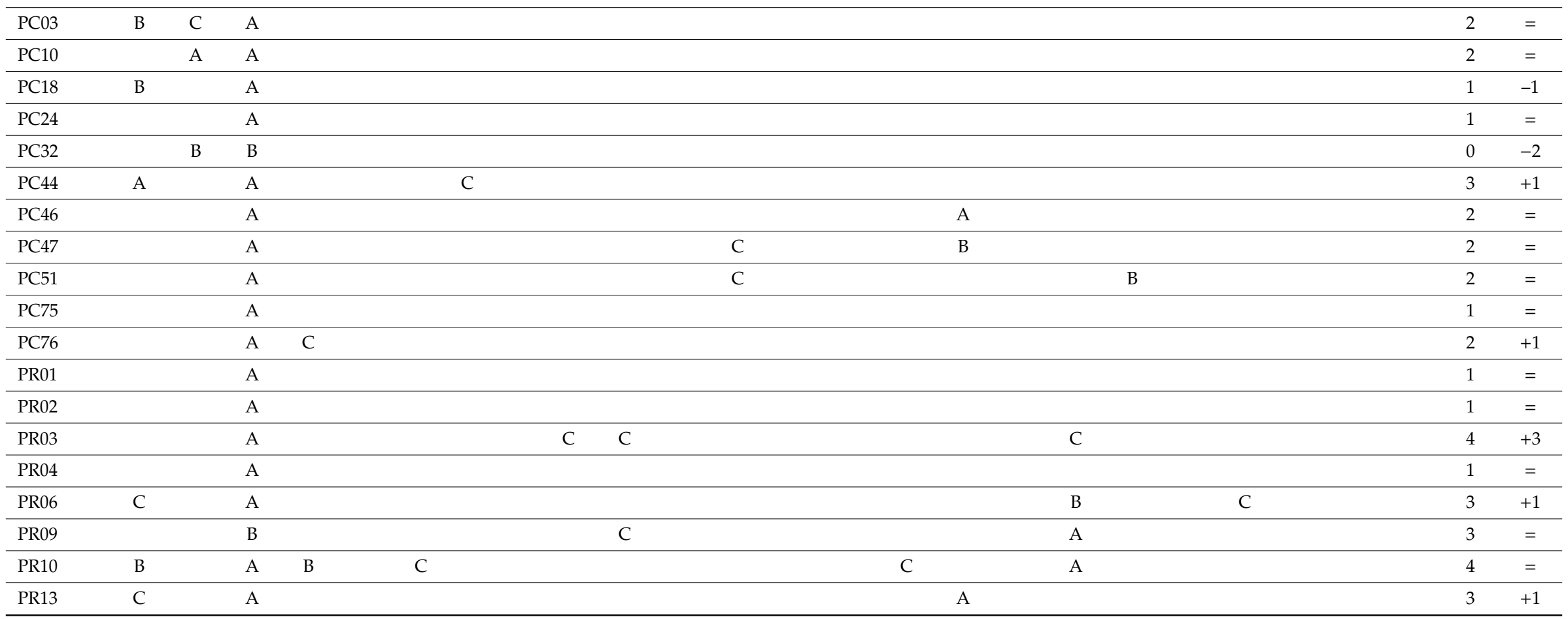


Table 2. Cont.

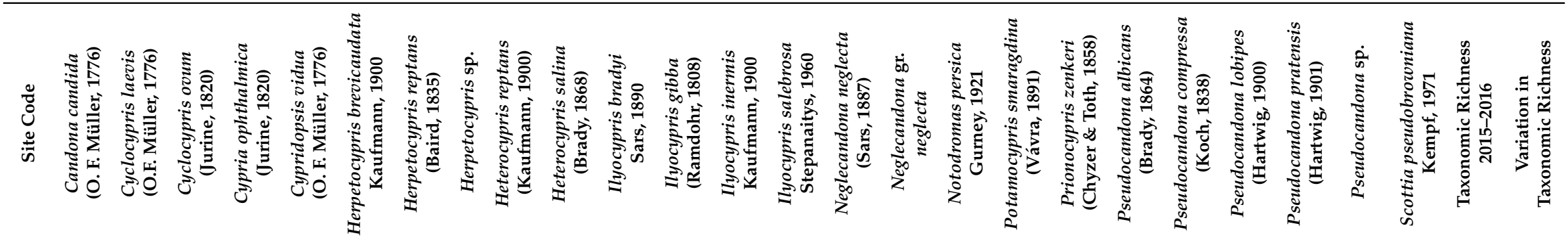

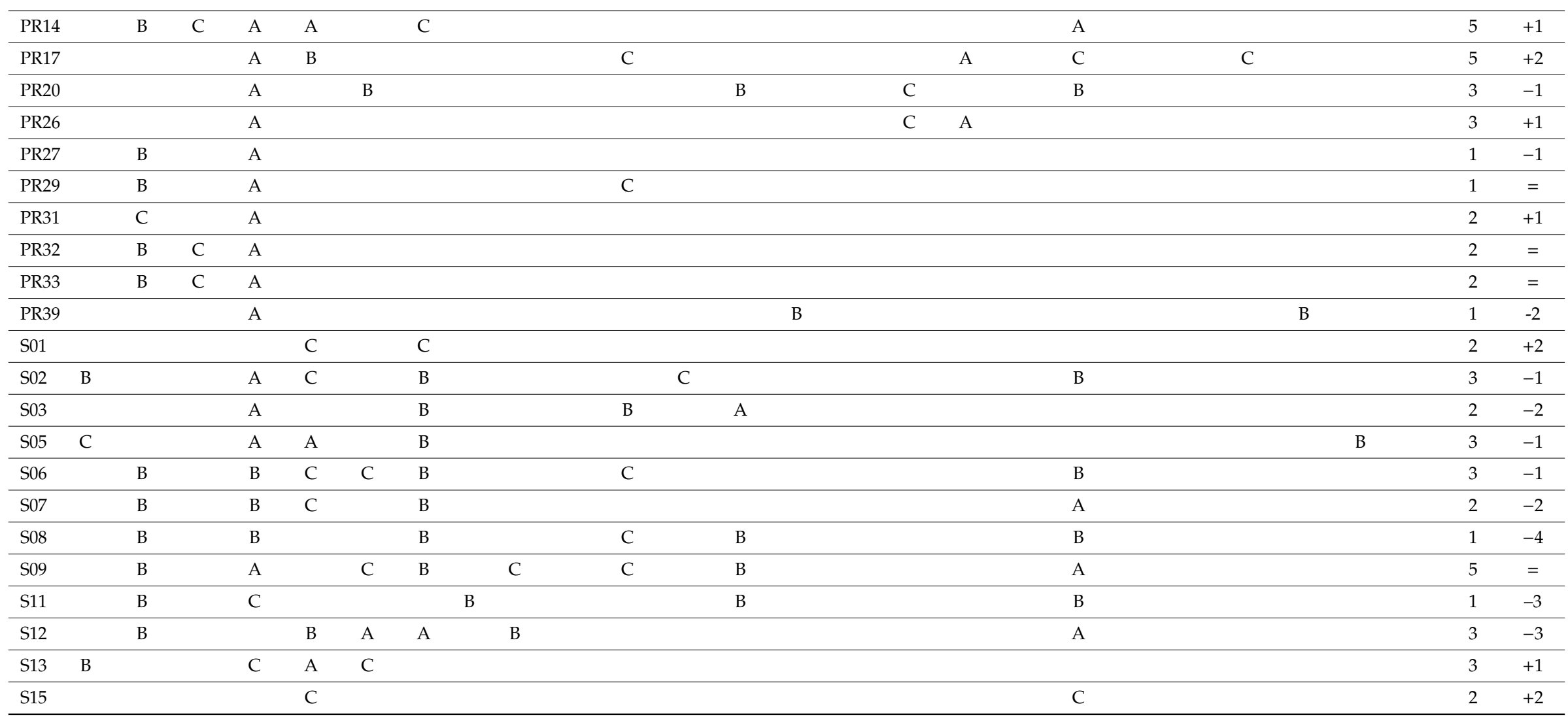


Table 2. Cont

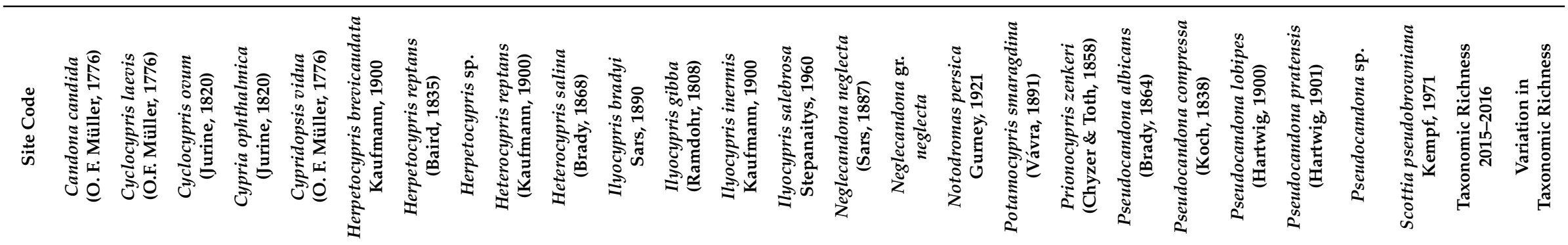

\begin{tabular}{|c|c|c|c|c|c|c|c|c|c|c|c|c|c|c|c|c|c|c|c|c|c|c|c|c|c|c|c|}
\hline S17 & & & & B & B & & & & & & & $\mathrm{C}$ & & & & & & & $\mathrm{B}$ & & & & & & & 1 & -2 \\
\hline S21 & & B & & $\mathrm{A}$ & & $\mathrm{A}$ & & & & & & & $B$ & & & & & & & & & & & & A & 3 & $=$ \\
\hline S22 & & & & & $\mathrm{A}$ & B & & & & & & & & & & & & & & & $B$ & & & & & 1 & -2 \\
\hline S23 & & & & $\mathrm{A}$ & $\mathrm{A}$ & & $\mathrm{A}$ & & & & & & & & & & & & $\mathrm{C}$ & & & & & & & 4 & +1 \\
\hline S24 & & & & $\mathrm{A}$ & $\mathrm{A}$ & C & B & & & & & & & & & & & & $\mathrm{C}$ & & & & & & & 4 & +1 \\
\hline S25 & & & & $\mathrm{B}$ & & & $\mathrm{A}$ & & & & & & & & & & & & $\mathrm{A}$ & & & & & & & 2 & -1 \\
\hline S26 & & & & $\mathrm{A}$ & B & & A & & & & & & & & & & & & $\mathrm{A}$ & & & & & & & 3 & -1 \\
\hline S27 & & & & & $\mathrm{C}$ & B & B & B & B & & & & $\mathrm{C}$ & & B & & & $\mathrm{C}$ & & & & & & & & 3 & -2 \\
\hline S28 & & & & B & $\mathrm{A}$ & & $B$ & & & & & & & & & & & & B & & & & & & & 1 & -3 \\
\hline$\Sigma$ & 1 & 4 & 5 & 37 & 14 & 5 & 7 & 1 & 1 & 1 & 7 & 2 & 4 & 0 & 0 & 3 & 5 & 1 & 11 & 0 & 0 & 2 & 0 & 0 & 1 & & \\
\hline
\end{tabular}


The relationships among abiotic variables and ostracod taxa are shown in the CCA triplot (Figure 5). Because they were significantly correlated with EC ( $p>0.05)$, four variables (TA, SRP, DIN and DRSi) were excluded from the analysis. The permutation tests indicated that the CCA was significant (Trace $=0.6918, p=0.003)$, as well as the first three canonical axes $(p<0.05)$. The first two axes of the CCA ordination accounted for $51.51 \%$ and $30.78 \%$ of the total explained variance.

Most of the taxa are grouped around the origin of the axes. The majority of the ostracods found only in the Emilia-Romagna springs are on the right side in the triplot, related to higher solute content. Heterocypris salina and Candona candida are clearly separated from the central cloud of points, and are in reciprocally opposite positions along both the first and second axis of the CCA. Heterocypris salina was recorded in a spring (PR03) with the highest conductivity value measured in the study area $\left(2037 \mu \mathrm{S} \mathrm{cm}{ }^{-1}\right.$ ), and Candona candida was recorded only in one site (S05), which was characterized by the lowest EC, TA and DRSi values in the entire study area.

\section{Discussion}

The results of this study indicate a rapid worsening of environmental conditions in a number of lowland springs, as can be inferred from changes in water quality and, to a lesser extent, also in their hydrological and biological features. These aspects are discussed in detail, taking into account the context of growing anthropogenic pressures on agricultural soils and water resources, and the effects resulting from their mutual interactions and feedbacks.

\subsection{Effects of Hydrological Factors and Agricultural Practice on Water Quality}

This study, contrarily to what was previously described, highlights the marked variability of the environmental conditions of lowland springs, which are mainly linked to hydrological factors and multiple stressors operating at local scales and which, in turn, have repercussions for the composition and stability of the ostracod communities. In addition, the comparison with previous data shows that these ecosystems are subject to rapid changes, with a trend towards losses of functionality and reduced efficiency in negative feedbacks.

Because of the more powerful aquifers that are recharged by water infiltration from Alpine watersheds compared to those in the Apennine area, the lowland springs in Lombardy have higher discharges and hydrological stability than the ones in Emilia-Romagna [46,47]. These latter, in fact, may undergo wide seasonal fluctuations in water level, and some may occasionally dry out due to water table lowering related to periods of low precipitation, intense water withdrawal for sprinkler irrigation and a prevalently intermittent hydrological regime of watercourses [48]. We therefore hypothesized that poor maintenance, and not water scarcity, is the main cause of drying in the seven springs in Lombardy, as reported in this survey.

Water scarcity in the right side of the Po river basin may cause an increase in solute concentration when water demand is the highest and supply is the lowest, typically in summer, when typical local crops, like tomatoes, are grown. On the Alpine side of the Po basin, water is much more readily available thanks to the higher and more continuous flows of rivers, which are in some cases further guaranteed by water released from regulated subalpine lakes, as in the Adda river [48]. Therefore, in Lombardy, soil submersion and flood irrigation are very common. These techniques favor the recharge of the aquifers on which the springs depend, and thus also a gradual increase in their discharge rate. If soils are fertilized, irrigation also leads to a delivery of nutrients to groundwater; on the other hand, large irrigation water volumes can also increase solute dilution $[49,50]$.

Different agricultural practices and crop types have varying effects on groundwater quality. In Emilia-Romagna, the autumn increase in DIN is compatible with nitrogen infiltration from soils fertilized in late summer for winter crop sowing (e.g., winter wheat and barley). Lower values in groundwater are likely due to either higher nitrogen uptakes by growing crops or possible denitrification. Higher DRSi values in summer can be related to a greater Si concentration due to the decrease in stored groundwater volumes, but also to infiltration from fields cultivated with cereals. Conversely, lower 
values in autumn may depend on a higher dilution; the reduction in the quantities of manure which returned to fields and the lack of cereal straw burial can further exacerbate such a decrease in DRSi concentration [51].

In Lombardy, permanent meadows and corn (mostly harvested at a waxy maturation stage) prevail; DIN does not increase in autumn because there is no tillage for the sowing of winter cereals, and the low concentrations in DRSi may be due to dilution, the water that infiltrates into aquifers being low in Si [48-50].

\subsection{Trends in Physico-Chemical Characteristics of Spring Waters}

The comparison of the physico-chemical water variables between both spring areas and surveys conducted in different years (Table 1; Figures 2 and 3) must be considered with some caution due to the aforementioned differences in hydrological conditions, irrigation practices, crop types and, for Emilia-Romagna springs, site sampling periods. Nevertheless, some trends are detectable.

Water temperature generally exhibited low variability, apart some evident deviations, both positive and negative, from average values in some springs of Emilia-Romagna (Figure 2), where the groundwater is more influenced by meteoclimatic conditions due to small stored water volumes and/or reductions in aquifer recharge due to excessive withdrawal. A reduction in the outflows has the effect of transforming the springs from rheo-limnocrenic to more markedly lentic systems, with a consequent greater variability in the physical and chemical characteristics of the water.

The positive linear correlation between TA and EC emphasizes how changes in solute concentrations are comparable in both the Apennine and Alpine sides of the Po river. They likely depend upon groundwater budgets, the water abstraction being responsible of water shortages and concentration increases, while the infiltration of soft water, e.g., from perialpine lakes in the Alpine side of the Po plain, may induce dilution. The other variables usually show marked changes (Table 1). In particular, our results revealed a decline in water quality, more evident in the springs located in Emilia-Romagna, related to the "nitrogen legacy" from the past half century, when high nitrogen amounts were delivered to the farmland through massive applications of fertilizers and manure, resulting in a feedback loop between soil and water use [48,52,53]. In addition, in the whole study area a marked decrease in dissolved reactive silica is supposed to occur, related to changes in both cultivation and breeding practices and crop typologies in the last decades [51,54]. SRP concentrations were always very low, and often undetectable, because of an effective geochemical control of P availability due to the soils being rich in $\mathrm{Ca}$ and carbonates. In the Po river basin, $\mathrm{N}$ and $\mathrm{P}$ surpluses increased until the 1990s, then P markedly decreased, whilst $N$ remained rather high [53]. The nutrient imbalance towards an $\mathrm{N}$ excess is further likely aggravated by the Si shortage, with potential impacts on aquatic vegetation/primary producers [51,54].

\subsection{Structure, Distribution Patterns and Evolution of Ostracod Assemblages}

The ostracod communities of the studied lowland springs are generally composed of species that are commonly found in Northern Italy [26], and that are characterized by wide ecological tolerance. A notable exception is Ilyocypris salebrosa, which, however, was not found in the PR39 spring where it was present in 2001, and so far this is the only record of this species for Italy [26,43].

Some of the collected ostracod species (e.g., Herpetocypris brevicaudata, Ilyocypris bradyi, Ilyocypris inermis, Prionocypris zenkeri, Scottia pseudobrowniana) can be considered crenophilous, being usually associated to springs or waters connected to springs [44]. Scottia pseudobrowniana, recovered from mosses in S21, is restricted to semi-terrestrial conditions [44]. No stygobiont or non-native species were found in the sampled sites. Of the two species that are clearly separated from the central cluster of the CCA (Figure 6), Heterocypris salina does indeed reflect its actual preference for salty waters, while the isolated position of the euryecious Candona candida simply depends on the physico-chemical characteristics of the only spring in which it occurs (S05). 


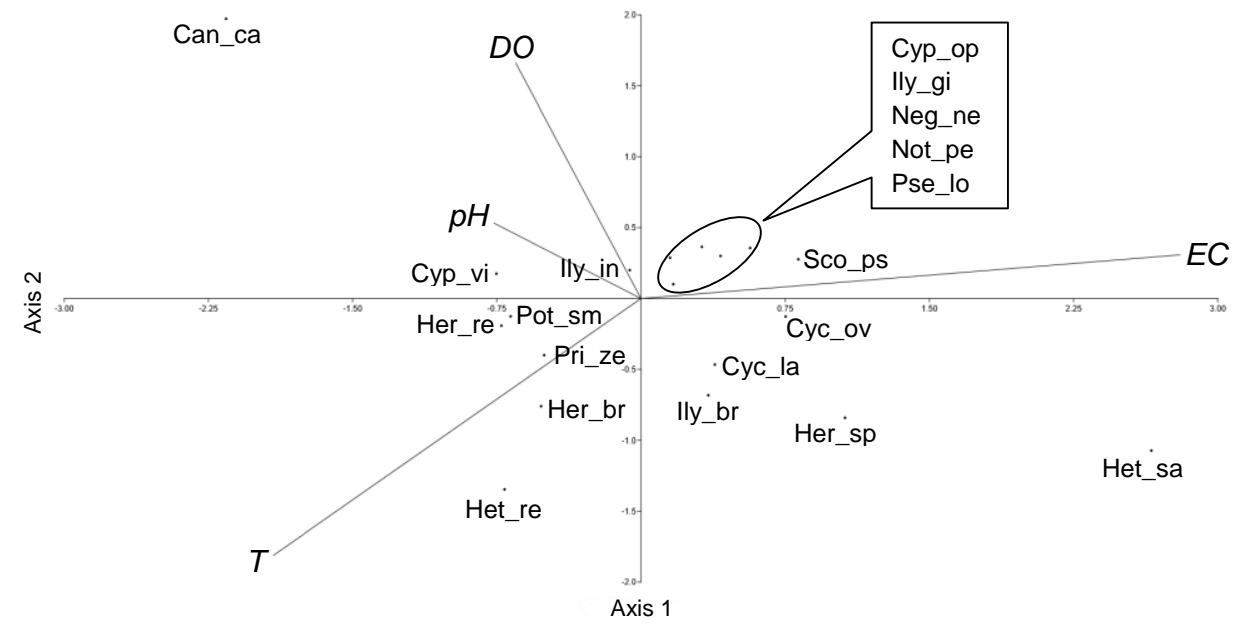

Figure 6. Canonical correspondence ordination of ostracods and environmental variables on the space defined by the first two canonical axes. The only significant variables $(p<0.05)$ in explaining species occurrence are displayed. Can_ca: Candona candida; Cyc_la: Cyclocypris laevis; Cyc_ov: Cyclocypris ovum; Cyp_op: Cypria ophthalmica; Cyp_vi: Cypridopsis vidua; Her_br: Herpetocypris brevicaudata; Her_re: Herpetocypris reptans; Her_sp: Herpetocypris sp.; Het_re: Heterocypris reptans; Het_sa: Heterocypris salina; Ily_br: Ilyocypris bradyi; Ily_gi: Ilyocypris gibba; Ily_in: Ilyocypris inermis; Neg_ne: Neglecandona gr. neglecta; Not_pe: Notodromas persica; Pot_sm: Potamocypris smaragdina; Pri_ze: Prionocypris zenkeri; Pse_lo: Pseudocandona lobipes; Pse_pr: Pseudocandona pratensis; Sco_ps: Scottia pseudobrowniana.

The ostracod assemblages of the lowland springs are generally simple, as they are expected to be in crenal habitats [10]. However, comparing the specific richness with that reported in previous studies in the same springs, it can be seen that the average number of species goes from 3.6 in 2004 to 2.5 in 2015 in Lombardy, and remains substantially stable in Emilia-Romagna (from 2.0 in 2001 to 2.2 in 2015-2016); in both cases, these are lower values than those reported for the rheo-limnocrenic springs of the Palearctic region $(4.7 \pm 2.7)$ [55]. The observed ostracod species diversity may be influenced by the sampling period. Pieri et al. [15] reported that out of the 16 ostracod taxa collected in lowland springs from Lombardy, 9 were present in both summer and autumn samples, 5 only in summer and 2 only in autumn. This and, for some species, the presence of larval stages only, likely indicates the different phenological behaviors for ostracods even in habitats where water temperature varies within a narrow range.

Some differences in the ostracod distribution exist between springs in Emilia-Romagna and Lombardy, possibly related to different concentrations of the dissolved inorganic fraction, in particular nitrogen, as evidenced by the results of the CCA (Figure 4). Nevertheless, no relationships between ostracod community similarity and spatial distance were found. The low similarity in species composition between geographically proximate springs does not seem to be attributable to a low dispersal capacity of ostracods. Frequent disturbances may lead to local extinctions followed by colonizations from nearby sites in spring ostracods communities, according to source-sink dynamics; under such conditions, stochastic processes might be more influential than environmental characteristics in shaping ostracod assemblages during early recolonization [56]. In addition, over a longer time scale, differences in environmental conditions occurring in adjacent springs may also determine the occurrence of species which, though generally widespread in Northern Italy, in our study have been shown to belong to a restricted number of genera compared to the full regional pool [26]. The above-stated hypotheses are supported by the high species turnover observed in the study area (Table 2).

The results on ostracod assemblages only partially agree with those found for other fontanili-dwelling communities. Despite the progressive worsening of their environmental conditions, the lowland springs of the Po river plain still act as important refuge habitats for both plant and animal 
stenothermal and/or rare species [3,57-60]. However, swift changes in species and functionality were recently reported for fish communities in response to temperature increases, invasions of exotic fish, and habitat quality degradations [61].

\section{Conclusions}

The lowland springs of the Po river plain can be regarded as important sentinels of environmental changes because the monitoring of their hydrological, hydrochemical and biological conditions provides useful information on the present status and trends of an area subjected to multiple interacting pressures.

The alleged stability of the lowland springs is usually observed in the case of water temperature, while hydrochemical variables show more or less wide variations over a period of 10-15 years. Hydrological characteristics and agriculture practices cause clear differences in water quality and in ostracod composition, both between catchments and frequently also within the same sub-catchment, indicating a strong dependence of springs on local impacts. In general, the trends of the stoichiometric ratios of the major nutrients indicate breakdowns of the biogeochemical cycles due to multiple impacts. Ostracod communities are generally characterized by a low alpha diversity and a high species turnover, which seem to be indicative of severe disturbances due the variability of environmental conditions.

The future climate is likely to further emphasize the fragility of these vulnerable ecosystems, as a result of a greater demand for water. Actions must be put in place to counter the deterioration or even the disappearance of these lowland springs, and more generally the GDEs, which constitute essential elements of the landscape of the Po valley, as well as aquatic biodiversity hotspots in a heavily modified agricultural area. An effective implementation of good agricultural practices to minimize the nitrate contamination, as well as contamination from the emerging contaminants of groundwater, is imperative. In addition, more effective guidelines for the correct maintenance of these ecosystems are needed to preserve or improve their hydraulic and ecological functionality. In this regard, a better integration between ecological and hydrogeological approaches in studying GDEs is essential so as to better understand the dynamics of these systems and their responses to climate change and human pressures.

Supplementary Materials: The following are available online at http://www.mdpi.com/2073-4441/12/11/3276/s1, Table S1: Geographic characteristics of springs and sampling dates of the 2015-2016 survey.

Author Contributions: All authors contributed equally to paper conceptualization, methodology setup and original draft preparation; V.P. and R.B. - sampling; D.N. and V.P.—sample analysis; G.R., V.P. and D.N.— data analysis and validation; G.R., D.N., R.B. and P.V.-review; G.R.-editing. All authors have read and agreed to the published version of the manuscript.

Funding: This research received no external funding. V.P. was supported by the "Associazione Interregionale Partecipazione e Studi in Agribusiness Paesaggio e Ambiente" (IPSAPA) and the "Ecoistituto del Friuli Venezia Giulia" in the frame of the project "Studio della diversità dell'ostracodofauna delle acque dolci come indicatore di pressione antropica sui sistemi agro-alimentari" (2015-2016).

Acknowledgments: Selena Ziccardi, Alessandro Scibona (University of Parma) are acknowledged for their support in different stages of this study.

Conflicts of Interest: The authors declare no conflict of interest.

\section{References}

1. Kløve, B.; Ala-Aho, P.; Bertrand, G.; Boukalova, Z.; Ertürk, A.; Goldscheider, N.; Ilmonen, J.; Karakaya, N.; Kupfersberger, H.; Kvœrner, J.; et al. Groundwater dependent ecosystems. Part I: Hydroecological status and trends. Environ. Sci. Policy 2011, 14, 770-781. [CrossRef]

2. De Luca, D.A.; Destefanis, E.; Forno, M.G.; Lasagna, M.; Masciocco, L. The genesis and the hydrogeological features of the Turin Po Plain fontanili, typical lowland springs in Northern Italy. Bull. Eng. Geol. Environ. 2014, 73. [CrossRef]

3. Abdelahad, N.; Bolpagni, R.; Lasinio, G.J.; Vis, M.L.; Amadio, C.; Laini, A.; Keil, E.J. Distribution, morphology and ecological niche of Batrachospermum and Sheathia species (Batrachospermales, Rhodophyta) in the fontanili of the Po plain (northern Italy). Eur. J. Phycol. 2015, 50, 318-329. [CrossRef] 
4. Fumagalli, N.; Senes, G.; Ferrario, P.S.; Toccolini, A. A minimum indicator set for assessing fontanili (lowland springs) of the Lombardy Region in Italy. Eur. Countrys. 2017, 9, 1-16. [CrossRef]

5. Cantonati, M.; Füreder, L.; Gerecke, R.; Jüttner, I.; Cox, E.J. Crenic habitats, hotspots for freshwater biodiversity conservation: Toward an understanding of their ecology. Freshw. Sci. 2012, 31, 463-480. [CrossRef]

6. Zanini, A.; Petrella, E.; Sanangelantoni, A.M.; Angelo, L.; Ventosi, B.; Viani, L.; Rizzo, P.; Remelli, S.; Bartoli, M.; Bolpagni, R.; et al. Groundwater characterization from an ecological and human perspective: An interdisciplinary approach in the Functional Urban Area of Parma, Italy. Rend. Lincei Sci. Fis. Nat. 2018, 30, 93-108. [CrossRef]

7. Soana, E.; Balestrini, R.; Vincenzi, F.; Bartoli, M.; Castaldelli, G. Mitigation of nitrogen pollution in vegetated ditches fed by nitrate-rich spring waters. Agric. Ecosyst. Environ. 2017, 243, 74-82. [CrossRef]

8. Balestrini, R.; Delconte, C.; Palumbo, M.; Buffagni, A. Biotic control of in-stream nutrient retention in nitrogen-rich springs (Po Valley, Northern Italy). Ecol. Eng. 2018, 122, 303-314. [CrossRef]

9. Minelli, A. (Ed.) Springs and Spring Watercourses-Springs in the Northern Italian Plains; Italian Habitats, Italian Ministry of the Environment and Territory Protection, Friuli Museum of Natural History: Udine, Italy, 2001; 154p.

10. Rossetti, G.; Pieri, V.; Martens, K. Recent ostracods (Crustacea, Ostracoda) found in lowland springs of the provinces of Piacenza and Parma (Northern Italy). Hydrobiologia 2005, 542, 287-296. [CrossRef]

11. Cantonati, M.; Poikane, S.; Pringle, C.M.; Stevens, L.E.; Turak, E.; Heino, J.; Richardson, J.S.; Bolpagni, R.; Borrini, A.; Cid, N.; et al. Characteristics, Main Impacts, and Stewardship of Natural and Artificial Freshwater Environments: Consequences for Biodiversity Conservation. Water 2020, 12, 260. [CrossRef]

12. Gandolfi, G.; Zerunian, S.; Torricelli, P.; Marconato, A. I Pesci Delle Acque Interne Italiane; Ministero dell'Ambiente, Unione Zoologica Italiana. Istituto Poligrafico e Zecca dello Stato: Roma, Italy, 1991.

13. Barbaresi, S.; Gherardi, F. The Invasion of the Alien Crayfish Procambarus clarkii in Europe, with Particular Reference to Italy. Biol. Invasions 2000, 2, 259-264. [CrossRef]

14. Bracco, F.; Paradisi, S.; Sburlino, G.; Stoch, F. Degradation and conservation. In Springs and Spring Watercourses-Springs in the Northern Italian Plains; Minelli, A., Ed.; Italian Habitats, Italian Ministry of the Environment and Territory Protection, Friuli Museum of Natural History: Udine, Italy, 2001; pp. 123-139.

15. Pieri, V.; Caserini, C.; Gomarasca, S.; Martens, K.; Rossetti, G. Water quality and diversity of the Recent ostracod fauna in lowland springs from Lombardy (northern Italy). Hydrobiologia 2007, 585, 79-87. [CrossRef]

16. Balderacchi, M.; Perego, A.; Lazzari, G.; Muñoz-Carpena, R.; Acutis, M.; Laini, A.; Giussani, A.; Sanna, M.; Kane, D.; Trevisan, M. Avoiding social traps in the ecosystem stewardship: The Italian Fontanile lowland spring. Sci. Total. Environ. 2016, 539, 526-535. [CrossRef] [PubMed]

17. Laini, A.; Bartoli, M.; Castaldi, S.; Viaroli, P.; Capri, E.; Trevisan, M. Greenhouse gases $\left(\mathrm{CO}_{2}, \mathrm{CH}_{4}\right.$ and $\left.\mathrm{N}_{2} \mathrm{O}\right)$ in lowland springs within an agricultural impacted watershed (Po River Plain, northern Italy). Chem. Ecol. 2011, 27, 177-187. [CrossRef]

18. Balestrini, R.; Sacchi, E.; Tidili, D.; Delconte, C.; Buffagni, A. Factors affecting agricultural nitrogen removal in riparian strips: Examples from groundwater-dependent ecosystems of the Po Valley (Northern Italy). Agric. Ecosyst. Environ. 2016, 221, 132-144. [CrossRef]

19. Battegazzore, M.; Morisi, A. Environmental evaluation of springs in the intensely cultivated and industrialized inland plain of Cuneo (Northwest Italy). J. Environ. Sci. Eng. 2012, B1, 19-24.

20. Shestani, L.; Morisi, A.; Fenoglio, S. Qualità ecologica dei fontanili di Cavallermaggiore nel periodo 1993-2006. St. Trent. Sc. Nat., Acta Biol. 2007, 83, 123-128.

21. Viaroli, P.; Rossetti, G.; Bertolini, S.; Pieri, V.; Venturelli, G.; Bernini, F.; Mozzanica, E.; Pedrelli, C. Qualità ambientale e problemi di conservazione dei fontanili nella pianura tra Piacenza e Parma. St. Trent. Sc. Nat. Acta Biol. 2003, 80, 181-183.

22. Gavazza, E.; Bolis, C.; Donelli, E.; Ravizza, L.; Camatini, M. Procedure standard ai sensi del D.Lgs. 152/99 per la valutazione dello stato di qualità dei fontanili della Provincia di Milano. Inquinamento 2003, 45, 52-56.

23. Laini, A.; Bartoli, M.; Lamastra, L.; Capri, E.; Balderacchi, M.; Trevisan, M. Herbicide contamination and dispersion pattern in lowland springs. Sci. Total Environ. 2012, 438, 312-318. [CrossRef]

24. Vasileiadis, S.; Puglisi, E.; Arena, M.; Cappa, F.; Van Veen, J.A.; Cocconcelli, P.S.; Trevisan, M. Soil microbial diversity patterns of a lowland spring environment. FEMS Microbiol. Ecol. 2013, 86, 172-184. [CrossRef] [PubMed] 
25. Meisch, C.; Smith, R.J.; Martens, K. A subjective global checklist of the extant non-marine Ostracoda (Crustacea). Eur. J. Taxon. 2019, 492. [CrossRef]

26. Pieri, V.; Martens, K.; Meisch, C.; Rossetti, G. An annotated checklist of the Recent non-marine ostracods (Ostracoda: Crustacea) from Italy. Zootaxa 2015, 3919, 271. [CrossRef] [PubMed]

27. Mezquita, F.; Griffiths, H.I.; Domínguez, M.I.; Lozano-Quilis, M.A. Ostracoda (Crustacea) as ecological indicators: A case study from Iberian Mediterranean brooks. Fundam. Appl. Limnol. Arch. Hydrobiol. 2001, 150, 545-560. [CrossRef]

28. Gifre, J.; Quintana, X.D.; De La Barrera, R.; Martinoy, M.; Marquèz, E. Ecological factors affecting ostracod distribution in lentic ecosystems in the Empordà Wetlands (NE Spain). Fundam. Appl. Limnol. Arch. Hydrobiol. 2002, 154, 499-514. [CrossRef]

29. Külköylüoğlu, O. On the usage of ostracods (Crustacea) as bioindicator species in different aquatic habitats in the Bolu region, Turkey. Ecol. Indic. 2004, 4, 139-147. [CrossRef]

30. Yilmaz, F.; Külköylüoğlu, O. Tolerance, optimum ranges and ecological requirements of freshwater Ostracoda (Crustacea) in Lake Aladag (Bolu, Turkey). Ecol. Res. 2006, 21, 165-173. [CrossRef]

31. Viehberg, F. Freshwater ostracod assemblages and their relationship to environmental variables in waters from northeast Germany. Hydrobiologia 2006, 571, 213-224. [CrossRef]

32. Allen, P.E.; Dodson, S.I. Land use and ostracod community structure. Hydrobiologia 2011, 668, $203-219$. [CrossRef]

33. Pieri, V.; Vandekerkhove, J.; Goi, D. Ostracoda (Crustacea) as indicators for surface water quality: A case study from the Ledra River basin (NE Italy). Hydrobiologia 2010, 688, 25-35. [CrossRef]

34. Coviaga, C.; Cusminsky, G.; Pérez, P. Ecology of freshwater ostracods from Northern Patagonia and their potential application in paleo-environmental reconstructions. Hydrobiologia 2017, 816, 3-20. [CrossRef]

35. Akdemir, D.; Külköylüoğlu, O.; Yavuzatmaca, M.; Tanyeri, M.; Gürer, M.; Alper, A.; Dere, Ş.; Çelen, E.; Yilmaz, O.; Özcan, G. Ecological Characteristics And Habitat Preferences Of Ostracoda (Crustacea) With A New Bisexual Population Record (Muğla, Turkey). Appl. Ecol. Environ. Res. 2020, 18, 1471-1487. [CrossRef]

36. Boomer, I.; Horne, D.J.; Slipper, I.J. The Use of Ostracods in Palaeoenvironmental Studies, or What can you do with an Ostracod Shell? Paléontol. Soc. Pap. 2003, 9, 153-180. [CrossRef]

37. Rodriguez-Lazaro, J.; Ruiz-Muñoz, F. A General Introduction to Ostracods. Dev. Quat. Sci. 2012, 17, 1-14. [CrossRef]

38. Smith, A.J.; Horne, D.J.; Martens, K.; Schön, I. Class Ostracoda. In Thorp and Covich's Freshwater Invertebrates; Elsevier BV: Amsterdam, The Netherlands, 2015; pp. 757-780.

39. APHA; AWWA; WPCF. Standard Methods for Examination of Water and Wastewater, 20th ed.; American Public Health Association: Washington, DC, USA, 1998.

40. Koroleff, F. Direct determination of ammonia in natural waters as indophenol blue. Information on techniques and methods for seawater analysis. Inf. Tech. Methods Seawater Anal. 1970, 3, 19-22.

41. Valderrama, J.C. The simultaneous analysis of total nitrogen and total phosphorus in natural waters. Mar. Chem. 1981, 10, 109-122. [CrossRef]

42. González Mozo, M.E.; Martens, K.; Baltanás, Á. A taxonomic revision of European Herpetocypris Brady and Norman, 1889 (Crustacea, Ostracoda). Bull. Inst. R.Sc. Nat. Belg. Biol. 1996, 66, 93-132.

43. Mazzini, I.; Gliozzi, E.; Rossetti, G.; Pieri, V. A multidisciplinary contribution to the Ilyocypris puzzle. Int. Rev. Hydrobiol. 2014, 99, 1-14. [CrossRef]

44. Meisch, C. Freshwater Ostracoda of Western and Central Europe; Spektrum Academischer Verlag GmbH: Berlin/Heidelberg, Germany, 2000; 522p.

45. Hammer, Ø.; Harper, D.A.T.; Ryan, P.D. PAST: Paleontological Statistics Software Package for education and data analysis. Palaeontol. Electron. 2001, 4, 2-9.

46. De Luca, D.A.; Lasagna, M.; Debernardi, L. Hydrogeology of the western Po plain (Piedmont, NW Italy). J. Maps 2020, 16, 265-273. [CrossRef]

47. Cantonati, M.; Segadelli, S.; Spitale, D.; Gabrieli, J.; Gerecke, R.; Angeli, N.; De Nardo, M.T.; Ogata, K.; Wehr, J.D. Geological and hydrochemical prerequisites of unexpectedly high biodiversity in spring ecosystems at the landscape level. Sci. Total. Environ. 2020, 740, 140157. [CrossRef] [PubMed]

48. Balestrini, R.; Delconte, C.; Sacchi, E.; Buffagni, A. Groundwater-dependent ecosystems as transfer vectors of nitrogen from the aquifer to surface waters in agricultural basins: The fontanili of the Po Plain (Italy). Sci. Total. Environ. 2021, 753, 141995. [CrossRef] [PubMed] 
49. Racchetti, E.; Salmaso, F.; Pinardi, M.; Quadroni, S.; Soana, E.; Sacchi, E.; Severini, E.; Celico, F.; Viaroli, P.; Bartoli, M. Is Flood Irrigation a Potential Driver of River-Groundwater Interactions and Diffuse Nitrate Pollution in Agricultural Watersheds? Water 2019, 11, 2304. [CrossRef]

50. Severini, E.; Bartoli, M.; Pinardi, M.; Celico, F. Reactive Silica Traces Manure Spreading in Alluvial Aquifers Affected by Nitrate Contamination: A Case Study in a High Plain of Northern Italy. Water 2020, 12, 2511. [CrossRef]

51. Viaroli, P.; Nizzoli, D.; Pinardi, M.; Rossetti, G.; Bartoli, M. Factors Affecting Dissolved Silica Concentrations, and DSi and DIN Stoichiometry in a Human Impacted Watershed (Po River, Italy). Silicon 2012, 5, 101-114. [CrossRef]

52. Bartoli, M.; Racchetti, E.; Delconte, C.A.; Sacchi, E.; Soana, E.; Laini, A.; Longhi, D.; Viaroli, P. Nitrogen balance and fate in a heavily impacted watershed (Oglio River, Northern Italy): In quest of the missing sources and sinks. Biogeosciences 2012, 9, 361-373. [CrossRef]

53. Viaroli, P.; Soana, E.; Pecora, S.; Laini, A.; Naldi, M.; Fano, E.A.; Nizzoli, D. Space and time variations of watershed $\mathrm{N}$ and $\mathrm{P}$ budgets and their relationships with reactive $\mathrm{N}$ and $\mathrm{P}$ loadings in a heavily impacted river basin (Po river, Northern Italy). Sci. Total Environ. 2018, 639, 1574-1587. [CrossRef] [PubMed]

54. Viaroli, P.; Bartoli, M.; Castaldelli, G.; Naldi, M.; Nizzoli, D.; Rossetti, G. Recent evolution and expected changes of nutrient loads in a heavily exploited watershed: The Po River, Italy. In Understanding Freshwater Quality Problems in a Changing World, Proceedings of H04, IAHS-IAPSO-IASPEI Assembly, Gothenburg, Sweden, 22-26 July 2013; Arheimer, B., Ed.; International Association of Hydrological Sciences: Wallingford, UK, 2013; Volume 361, pp. 175-182.

55. Rosati, M.; Cantonati, M.; Primicerio, R.; Rossetti, G. Biogeography and relevant ecological drivers in spring habitats: A review on ostracods of the Western Palearctic. Int. Rev. Hydrobiol. 2014, 99, 409-424. [CrossRef]

56. Rosati, M.; Cantonati, M.; Pieri, V.; Roca, J.R.; Mezquita, F.; Rossetti, G. Are aquatic assemblages from small water bodies more stochastic in dryer climates? An analysis of ostracod spring metacommunities. Hydrobiologia 2016, 793, 199-212. [CrossRef]

57. Fea, G.; Nardi, P.A.; Ghia, D.; Spairani, M.; Manenti, R.; Rossi, S.; Moroni, M.; Bernini, F. Dati preliminari sulla distribuzione in dei gamberi d'acqua dolce autoctoni e alloctoni. Atti Soc. ital. sci. nat., Mus. civ. stor. nat. Milano 2006, 147, 201-210.

58. Delmastro, G.B.; Balma, G.A.; Deandrea, G. L'ittiofauna Delle Risorgive in Piemonte Occidentale. The fishes of Lowland Springs in the Western Piedmont (North-Western Italy); Quaderni ETP-Ente Tutela Pesca del Friuli Venezia Giulia: Udine, Italy, 2006; Volume 34, pp. 9-19.

59. Pezzoli, E. Notes on new or rare taxa of Crustaceans and Molluscs from a "fontanile" in Arzago d'Adda, Bergamo, Italy (Crustacea, Mollusca). Biodivers. J. 2010, 1, 45-55.

60. Bischetti, G.; Fumagalli, N.; Gomarasca, S.; Pillitter, T.; Piantanida, E.; Senes, G.; Negri, G.; Marziali, L.; Toccolini, A. Tutela e valorizzazione dei fontanili del territorio lombardo. In Progetto FonTe; Quaderni della Ricerca n. 144; Regione Lombardia, D.G. Agricoltura: Milano, Italy, 2012; 102p.

61. Stefani, F.; Schiavon, A.; Tirozzi, P.; Gomarasca, S.; Marziali, L. Functional response of fish communities in a multistressed freshwater world. Sci. Total Environ. 2020, 740, 139902. [CrossRef] [PubMed]

Publisher's Note: MDPI stays neutral with regard to jurisdictional claims in published maps and institutional affiliations.

(C) 2020 by the authors. Licensee MDPI, Basel, Switzerland. This article is an open access article distributed under the terms and conditions of the Creative Commons Attribution (CC BY) license (http://creativecommons.org/licenses/by/4.0/). 